Re-thinking Latin America: Challenges and

Possibilities

\title{
Struggling for Another Life: The Ontology of Degrowth
}

\section{Katharina Richter}

\section{(2) OpenEdition \\ Journals}

Electronic version

URL: https://journals.openedition.org/transtexts/1242

DOI: $10.4000 /$ transtexts. 1242

ISSN: 2105-2549

Publisher

Gregory B. Lee

Electronic reference

Katharina Richter, "Struggling for Another Life: The Ontology of Degrowth", Transtext(e)s Transcultures 跨文本跨文化 [Online], 14 | 2019, Online since 31 December 2019, connection on 21 September 2021. URL: http://journals.openedition.org/transtexts/1242 ; DOI: https://doi.org/10.4000/transtexts. 1242

This text was automatically generated on 21 September 2021.

(c) Tous droits réservés 


\title{
Struggling for Another Life: The Ontology of Degrowth
}

\author{
Katharina Richter
}

The author would like to thank Dr Francisco Carballo, Professor Sanjay Seth, and everyone at the Goldsmiths Centre for Postcolonial Studies for their generous and kind support during the last few years. I would also like to thank the anonymous reviewers for their thoughtful and insightful comments on an earlier version of the text.

\section{Introduction}

1 This article has two aims. The first is to draw out some of the ontological assumptions that underlie the degrowth discourse. In doing so, I would like to develop recent attention to, and concern with the "Global South" in Anglophone degrowth literature in more detail. ${ }^{1}$ As such, this article should be of interest for degrowth scholars, but also practitioners, artists, and activists. The second aim is to introduce the central tenets and aims of the degrowth discourse to thinkers from disciplines such as postcolonial and cultural studies, or anthropology. This article will give a brief overview of degrowth in order to focus on one of the debate's limitations - an understanding of reality that is grounded in Cartesian dualism that separates nature from society. I will draw on the modernity/coloniality discourse to consider our way of thinking as the root cause of the current ecological crisis. I will argue that degrowth analyses that are based on ecological economics unwittingly perpetuate the "coloniality of nature." As a way forward, I suggest focusing on the theorisation of rights of nature, as well as considering ontological and epistemological alternatives to the Cartesian society/nature dichotomy and its associated subject/object hierarchy. The Buen Vivir paradigm, understood as an everyday, decolonial grassroots practice, is put forward as an example of another form of life that challenges and delinks from the coloniality of nature. 


\section{What Is Degrowth?}

2 Degrowth is a response to the multiple crises of our time, embodied in climate change and persistently growing inequalities within and between countries. The participants of the first degrowth conference in 2008 framed their project as a blueprint for "a voluntary transition towards a just, participatory, and ecologically sustainable society." ${ }^{2}$ Economic growth and environmental sustainability are thereby considered mutually exclusive. ${ }^{3}$ Sustainable degrowth is defined

as an equitable down-scaling of production and consumption that increases human well-being and enhances ecological conditions at the local and global level, in the short and long term. ${ }^{4}$

Degrowth first and foremost aims to abolish economic growth as a social objective. ${ }^{5}$ Its literature pays equal attention to social equality and ecological sustainability policies. ${ }^{6}$ The proposed socioeconomic overhaul would require political action on international, national, regional and grassroots levels. The term degrowth therefore not only encapsulates an academic debate, but a social and political movement. ${ }^{7}$

The political economy of degrowth has its intellectual roots in the ecological, cultural and political critiques of economic growth. The ecological critique of growth rests on ecological economics and physics - specifically, thermodynamics. Degrowth's cultural arguments are inspired by the sociological, anthropological, psychoanalytical and antiutilitarian critiques of homo oeconomicus, and the social limits to growth. ${ }^{8}$ Degrowth's political critiques of growth are mainly drawn from post-development and political ecology. ${ }^{9}$ The present analysis focuses on the ecological critique of growth for three reasons. Firstly, a systematic examination of the ways in which Cartesianism in built into degrowth's cultural and political critiques of growth is beyond the scope of this article. Secondly, others have already argued that degrowth's political critique of growth is grounded in structuralist, anthropocentric discourses on the environment. ${ }^{10}$ Thirdly, ontological enquiries into degrowth politics and activism have been based on the cultural critiques of growth. ${ }^{11}$ Consequently, this paper interrogates the ontological assumptions behind the ecological critique of growth that motivates degrowth scholarship and activism. Before doing so, the following paragraphs will introduce the main tenets of ecological economics in their relation to degrowth.

The heterodox school of ecological economics seeks to resituate the economy within the global ecological system (Figure 1)..$^{12}$ Invoking the second law of thermodynamics, scholars argue that infinite economic growth based on a finite supply of natural resources is a contradictory principle. ${ }^{13}$ Reducing energy and material throughput instead would allow the economy to operate within planetary boundaries, as economic activity depends on ecosystems' functioning as both sources and sinks. ${ }^{14}$ Compounding this problem is Jevons' paradox, also known as the rebound effect. 


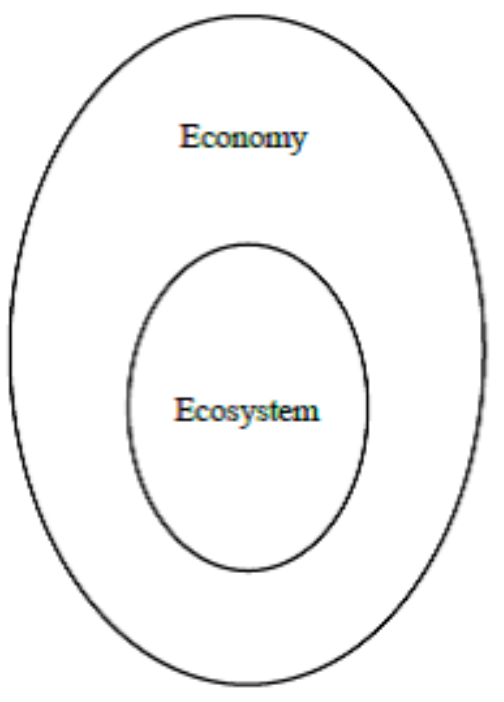

Neo-classical Economics

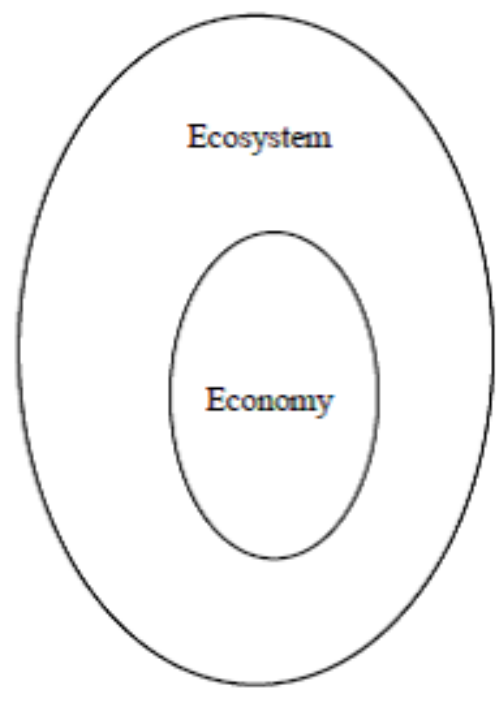

Ecological Economics

Figure 1: Neo-classical vs. ecological economics (adapted and modified from Herman E. Daly and Joshua C. Farley, Ecological Economics: Principles and Applications, 2nd ed., Washington, DC, Island Press, 2011, p. 51.)

Jevons found that productivity and relative efficiency gains in resource use lead to an increase in its total consumption..$^{15}$ Aggregate environmental impact has been shown to remain severe despite technological improvements (e.g. energy efficiency), decreased consumption of goods and services per person, and/or population control measures. ${ }^{16}$ Absolute carbon and resource caps, coupled with environmental taxes, are considered feasible policies to resolve Jevons' paradox. They could decrease bio-physical throughput without producing leakages (i.e. shifting pollution) and rebounds elsewhere. ${ }^{17}$

The production and use of electric and hybrid vehicles is forecasted to rise from 3 million in 2017 to 27 million in 2027, with a concomitant increase in copper demand by an estimated 9.4 times. $^{18}$ The "Responsible Copper Initiative," a 2018 deal between German carmaker BMW and Chilean mining company Codelco, planned to target areas in the Ecuadorian cloud forest of Intag, part of the Tropical Andes Biodiversity hotspot. Since previous Codelco activity in the same area has been criticised for human and environmental rights violations, the deal would have likely led to more environmental disasters. ${ }^{19}$ It was cancelled after environmental activists travelled from Intag to Munich to argue their case in front of BMW representatives. ${ }^{20}$ The Environmental Justice Atlas, however, shows the infrequency of such outcomes. ${ }^{21}$ Environmental justice in the Global South therefore hinges on degrowth in the Global North: the "down-scaling of production and consumption" by affluent communities in industrialised economies. ${ }^{22}$ Furthermore, the pervasiveness of Jevons paradox could be explored at the level at which it occurs: system level (civilisations, organisms), ${ }^{23}$ psychological (as some environmental literature suggests), ${ }^{24}$ or at the cultural level, which would allow for social and political action to overcome present challenges. Finally, the BMW-Codelco deal hints at the folly of green growth - the assumption that it's ecologically possible, or even desirable to switch from a fossil fuel to a renewable energy-based economy without the political, economic, and sociocultural changes proposed by degrowth. 
8 Degrowth's biophysical arguments originate from ecological economics. Its economic critique in turn is grounded in questioning market-based approaches to human wellbeing and environmental protection, given that the ostensible benefits of an expanding economic sphere and technological progress are said to have failed to materialise. ${ }^{25}$ This is evident in the severe inequality of living standards between and within countries and resulting health, violence or illiteracy issues. ${ }^{26}$ The rise of precarious work and unemployment further indicates the limits of growth-centred economic policies. ${ }^{27}$ In response, degrowth advocates propose universal basic and maximum incomes, work-sharing, state job guarantees and reductions in working hours as potential paths towards the construction of "convivial, autonomous and economical societies." ${ }^{28}$ People would work and consume less, but be more content and autonomous. ${ }^{29}$ This type of "frugal abundance" as a form of social organisation limits individual power according to the needs of others. ${ }^{30}$ It could be achieved by democratising economic and political decision-making, as well as commoning processes or institutions such as care, resources, money etc. ${ }^{31}$ This would require not only a downshift in material affluence, but political and cultural direction of the degrowth process.

9 Degrowth is understood as "an exploratory avenue, rather than a completed and sealed doctrine." ${ }^{32}$ As such, there are attempts to balance its central argument - to break with the logic of the market that pervades all aspects of life - with a technocratic focus on and call for more economic modelling within the ecological economics school of the debate. ${ }^{33}$ Certainly, indicators of degrowth ought to and have been formulated. ${ }^{34}$ This paper, however, argues that degrowth analyses based on an ecological critique of growth have so far hardly engaged with the construction of nature as apart from humans, and the effect this may have on their policy proposals and theories of value. The nature/culture dichotomy is inherent in the discipline of (ecological) economics, and by extension, the degrowth debate.

\section{The Modernity/Coloniality Discourse}

10 The modernity/coloniality discourse aims to reconceptualise our understanding of modernity from the perspective of the (Latin American) subaltern. Modernity is understood as a historical period during which Western civilisation's three "macronarratives" or pillars - Christian theology, secular philosophy and scientific (instrumental) reason - came to be seen as universal civilisationary benchmarks. ${ }^{35}$ This analysis rests on a shared understanding of Quijano's concept of "coloniality of power" and Dussel's "transmodernity." ${ }^{36}$ It presents three main arguments.

11 First, its authors compel us to view the industrial and scientific revolutions as facilitated and made possible by colonialism and European political, economic and cultural hegemony over the world, rather than a disembodied and dematerialised achievement of Western Europe and its (male) subjects. ${ }^{37}$ Secondly, they argue that modernity is constituted by a logic of domination that pervades every aspect of life. "Coloniality" consequently doesn't refer to specific historical periods or places of imperial domination, but to a logical structure of domination, under a variety of rulers and powers. ${ }^{38}$ Disguising provincialism (i.e. a historically specific culture) as universalism (i.e. a global set of values and development), this structural colonial domination imposes a specific cosmovision, i.e. the Euro-Atlantic civilisationary 
model's ontological and epistemological principles, onto the rest of the world. ${ }^{39}$ This control is exerted through the interaction of knowledge, racism and capital and manifests itself across four axes, known as the "Colonial Matrix of Power" (CMoP):

- the economy, founded on the racialised and gendered division of salaried and nonsalaried labour and its integration into the global market under capitalism, the creation of international governance bodies such as the IMF, the appropriation of land and natural resources that subordinates nature to the market and human activity;

- intersubjectivity and knowledge through epistemic repression, cultural assimilation for profit and the positioning of the European enlightenment and specifically rationality as civilisationary benchmark for all non-Europeans; control that extends beyond the education system to the lenses through which we view the world, its concepts and subjectivities (e.g. the "consumer," "citizens");

- sex and gender through the heteronormative, patriarchal control and appropriation of female reproductive and domestic labour as well as the imposition of binary and hierarchical gender notions, the notion of "woman" as a fixed identity and the nuclear family;

- authority through the formation of governments, for example in the form of modern nation states that control resources and products, but also militarism, international relations and rights..$^{40}$

13 Thirdly, the modernity/coloniality project builds on the colossal task of, in Mignolo's words, "de-linking" from the CMoP, specifically to decolonise knowledge and being. Epistemological and ontological decolonisation complement efforts to end the peripheral countries' political and economic colonisation, i.e. dependence on the industrialised core. ${ }^{41}$ In practice, this means challenging any power structure that isn't based on free decisions by free people. ${ }^{42}$ This would require "epistemic shifts" towards modes of enquiry that aren't based on Cartesianism, anthropocentrism or heteronormativity. ${ }^{43}$ "Decoloniality" demands the perpetual exposure of the geopolitical location of knowledge production while employing those ways of knowing and principles of knowledge that have been rendered invisible by the (neo)colonial processes of marketisation, Christianisation and development. ${ }^{44}$ This doesn't involve the rejection of modernity, so much as a redefinition of what emancipation and liberation (or indeed citizenship, democracy, economics) mean from the cosmological and epistemological view of the subaltern. ${ }^{45}$ The Zapatistas' geo-political revolution in 1994 for example resulted in a de facto secession from the Mexican state based on radical democracy and egalitarianism. Their understanding of governance is grounded in Tojolab'al epistemologies, shaped by a linguistic insistence on intersubjectivities. ${ }^{46}$ Lacking a subject/object correlation, the natural world and society are not represented as a series of objects, but a dynamic interaction between human and non-human subjects: to govern means to rule and obey at the same time by listening to one another, the mountains, or one's ancestors. ${ }^{47}$ The following section interrogates the ontological assumptions behind ecological critiques of economic growth before presenting viable alternatives to Cartesianism.

\section{The Ontology of Degrowth}

14 The advocates of degrowth want to change the economic system. To do so, degrowth cannot remain ahistorical. An analysis of how the legacies of colonialism and 
coloniality have come to shape our current world positions ecological debt and environmental justice (EJ) at the heart of the degrowth discourse. Embedding EJ as a principle of degrowth politics would overcome its Eurocentric focus and acknowledge that control over the economy and access to resources lies with the institutions, academies, governments and corporate interests of the Euro-Atlantic world. ${ }^{48}$ For indigenous peoples, climate change and neoliberal adaptation mechanisms represent an intensification of on-going and historic colonialism. ${ }^{49}$ Yet, discussions of colonialism - and its gendered effects, amongst others - are conspicuously absent from the degrowth discourse - a characteristic this paper aims to address with regards to Cartesian dualism and the conceptualisation of nature. The following paragraphs will sketch a brief genealogy of the idea of "nature."

Most social sciences rarely question the Cartesian nature/culture dichotomy that both underlies research and shapes the researcher's sociocultural understanding of Nature. In no science is this more prevalent than in economics. In economic analyses, the natural environment is considered external to human behaviour and the economic system. It appears as capital in production functions or resource in input-output analyses, in other words, as a sub-system to the economy rather than vice versa. ${ }^{50}$ Escobar calls the persistent subordination of nature to economic interests the "coloniality of nature." ${ }^{51}$ Shifting resource extraction and subsequent contamination, pollution, desertification and deforestation to the Global South and non-affluent areas of the Global North has furthermore racialised and gendered access to resources. ${ }^{52}$ In contrast to recent attention to gender and care, racial inequalities have rarely been examined in a degrowth context..$^{53}$ De-linking from the coloniality of gender and race goes hand in hand with de-linking from the coloniality of nature.

From a modernity/coloniality perspective, it is the very idea of Nature and the scientific revolution which, together with the other "imperial discoveries" of the Orient(al) and the "savage" laid the foundations of our current "civilisationary crisis." 54 The latter is exacerbated by the predominant view of both nature and the (indigenous) Other and their knowledges as profitable resources..$^{55}$ The appropriation of (tropical) nature via forced labour, i.e. the combination of social and environmental exploitation supplied the capital and resources required for the development of the steam engine, the banking and insurance and heavy industries - the eighteenth century cornerstones of capitalist modernity. ${ }^{56}$ This process was accompanied, and partly enabled by of the secularisation of European cosmology from the sixteenth century onwards. 


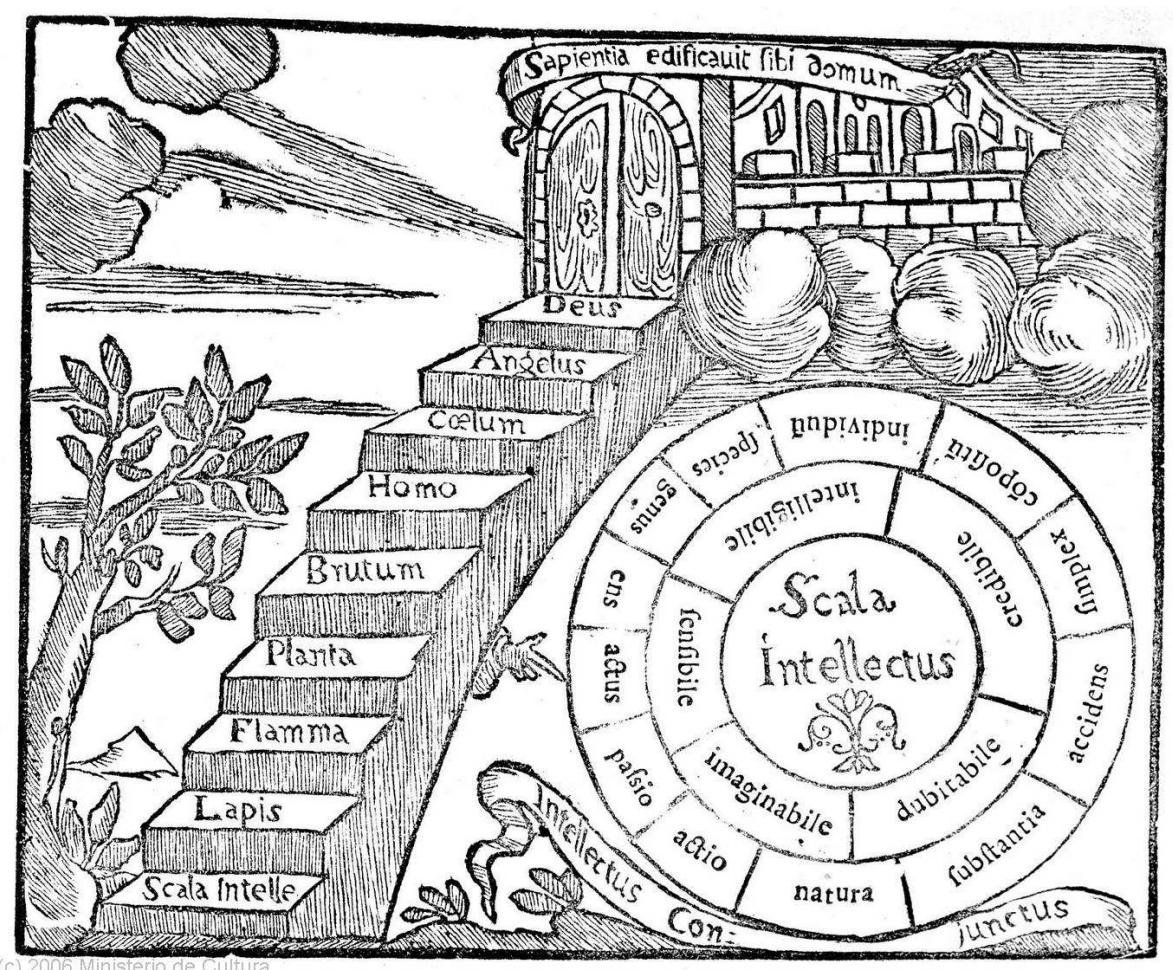

Figure 2: The Great Chain of Being, (Ramón Llull, Libro Del Ascenso y Descenso Del Entendimiento, Copia digital 2006, Madrid, Ministerio de Cultura, 1753, p. 12) (C) CC BY 4.0

Arguments that posit Christianity as the world's pre-eminent anthropocentric religion rest on the indifference towards the exploitation and destruction of the natural world it has created over time, not just by replacing pagan animism, but by insisting that man - made in God's image - is not just apart from nature, but has dominion over it. ${ }^{57}$ In medieval Christianity, the hierarchical image of the Great Chain of Being (Figure 2.) illustrated the elevated status of humans versus animals and plants. Certainly, the Great Chain of Being stands alongside a long history of Christian environmental movements such as the Diggers or Benedictine and Franciscan orders..$^{58}$ Contemporary evidence furthermore suggests no correlation between biblical beliefs and low environmental concern..$^{59}$ Nevertheless, the scientific revolution secularised those attitudes that were rooted in an interpretation of Genesis that sees this natural dominion not as a form of rule, but harmony..$^{60}$ The incessant interest in the discovery of natural laws through the scientific method trumped any reverence of nature as God's creation. Moreover, knowledge of nature came to be seen as means to "master and possess" it for the improvement of the human condition. ${ }^{61}$ The idea of perfecting nature by imposing shape and form onto it found expression in the ubiquitous geometric gardens of the Renaissance and Baroque periods. ${ }^{62}$ Much more sinister is the trajectory of the Cartesian view of nature in the colonial context.

The settlement and colonisation of Ireland and Virginia was based on ideas of "taming wilderness"; a reference to nature and people, both of which needed substantial transformation - into plantation economies - in order to be fit for civil (i.e. English) habitation: "( $t$ )he main problem facing the [Irish] landscape was the "wild and inhospitable people," while "(c)hanges to descriptions of Virginia's physical environment paralleled the changes in descriptions of Virginia's natives [Algonquians]." ${ }^{63}$ The Baconian subjugation of nature and the people in it was to be 
achieved through science: combining knowledge of something or someone with power over them. ${ }^{64}$ Nature was not necessarily constructed as an ontological entity per se, but as opposite to culture, i.e. inherently exterior to civilised Anglo-Saxon society. ${ }^{65}$ Eighteenth and nineteenth century economics continued this trajectory and summed up all natural resources, freely and infinitely available, under the umbrella term land, i.e. one of the factors of production. ${ }^{66}$ Despite Cartesianism's diminished role in contemporary philosophy, its basic epistemological and ontological assumptions (e.g. a focus on mathematical reason and the nature/culture divide) are built into economic theory and the global political economy.

In addition to economics, early modern European political theory further entrenched the nature/culture divide in state theory and ideals of liberty and freedom. For Hobbes and Rousseau, the state emerged "in opposition to a pre-statal condition, or state of nature." ${ }^{67}$ Connected to the political theory of Locke and Hobbes and the role of the state are ideas of private property. These emerged slowly, especially with regards to land, but were commonly accepted by the seventeenth century following a century of enclosure. The latter paved the way for formulations of political freedom that were and continue to be connected to individual possessions. ${ }^{68}$ The well-documented social - and ecological - effects of enclosure in England and Western Europe foreshadowed the violent appropriation, commercialisation, and exploitation of the rest of the world by European imperial powers during the Age of Empire. ${ }^{69}$ Across the world, unequal exchange as a form of violent state and (neo)imperial power has been creating a nature that is "governable."70 This persistent prioritisation of capital over ecology and society is expressed in the "coloniality of nature."

The view of nature as external to humans, established by the Cartesian opposition of mind/body and culture/nature, should be of interest to the Degrowth debate. It is one of the conditions "for the appropriation/exploitation that grounds the Western paradigm of unlimited growth." ${ }^{11}$ An analysis of nature as a cultural construct allows us to understand how deforestation, oil exploration and shale gas drilling largely happen because shareholders mandate that "the price is right." The "taming wilderness" discourse has evolved into the near-total annexation of "wild" nature and of people across the globe. The cattle, soy bean, and oil and gas driven deforestation of the Brazilian Amazon is but one example. ${ }^{72}$ "Provincialising nature" therefore entails the de-centring of the Cartesian epistemology and ontology that determine our approach to science and environmental politics. ${ }^{73}$ This de-centring must start with an acknowledgement of how it is built into degrowth policy proposals.

21 This is not to say that degrowthers fail to recognise the embeddedness of the human population within "nature" and our dependence on it. The central thesis of the Degrowth debate is that the economy is a sub-system of nature - in the form of global ecosystems. Yet, precisely in this aspect, the debate is seemingly unable to shake off preconceived notions inherited from ecological economics. In what is often considered the discipline's founding text, "The Economics of the Coming Spaceship Earth," Kenneth Boulding speaks of the earth as a system in which humans and nature interact and the former depend on the latter:

[All human societies] receive inputs from the earth, the atmosphere, and the waters, and they give outputs into these reservoirs; they also produce inputs internally in the shape of babies and outputs in the shape of corpses. ${ }^{74}$ 
There is no doubt about the revolutionary nature of this claim vis-à-vis economic theory in the Western academies of the 1960s. Furthermore, ecological economics language since then may have shifted from resources to that of materials. Yet, reducing living organisms, both sentient and non-sentient, to objectified in- and outputs facilitates the incorporation of these "materials" into economic models and by extension, the market. Some EJ groups from the Global South have rejected degrowth as an ally because of its anthropocentrism, amongst others. ${ }^{75}$ Shifting the language of degrowth away from materials towards "the living world" may start to break with this anthropocentrism. The "living world" could encompass sentient, spiritual, and supernatural beings, thereby allowing for ontological and epistemological pluralisms. ${ }^{76}$ Figure 3 contrasts the hierarchy of an anthropocentric worldview with an eco-, or cosmo-centric, non-hierarchical worldview.

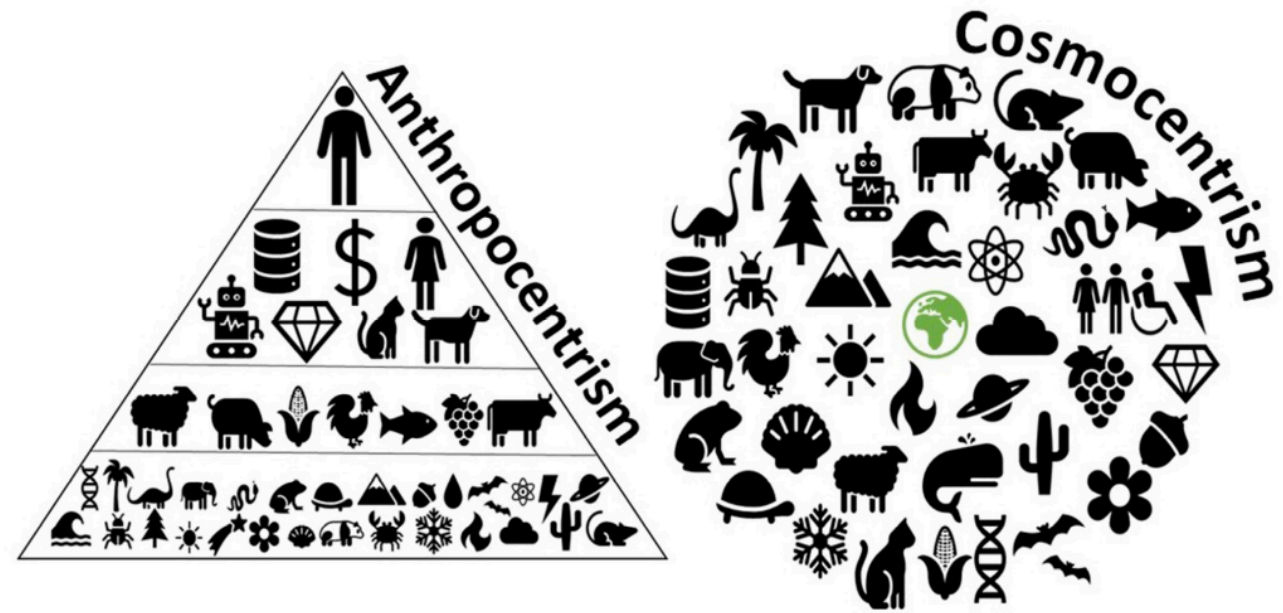

Figure 3: Anthropocentric vs eco-/ cosmo-centric view of life (in the context of Classic Mayan society). (Lisa J. Lucero and Jesann Gonzalez Cruz, "Reconceptualizing Urbanism: Insights from Maya Cosmology," Frontiers in Sustainable Cities, vol. 2, January 2020) (c) 2020 Lucero and Gonzalez Cruz

Yet, the contemporary degrowth discourse is bound up with ecological economics at the policy and practical level through the use of economic modelling. These methods conceptualise the living world as "materials" in policy proposals on income, work and money. ${ }^{77}$ If degrowth is to move beyond its European and Eurocentric focus, thinkers need to examine the construction of "nature" and its consequences for policy and practice. EJ activists raise a similar challenge to Western notions of "time", central to work-related Degrowth policy proposals. ${ }^{78}$ How do these notions clash with the time of the "pueblos" (communities, people), aboriginal or indigenous temporalities (like the Andean "Pacha"), and indeed, the times of nature? ${ }^{79}$ Eco-feminists similarly challenge the nature/culture divide and its consequences for women across the globe. ${ }^{80}$ Qualitative work with those who are already living local and culturally specific versions of degrowth may therefore be of interest to degrowth thinkers. ${ }^{81}$

24 I would like to suggest that the degrowth debate remains grounded in scientific principles but moves beyond Cartesian dualism and anthropocentrism in its analysis of our civilisationary crises. From a theoretical standpoint, the modernity/coloniality discourse is useful in uncovering how modernity and the CMoP are embedded in the degrowth discourse. This article focuses on one of its aspects - the coloniality of nature. Furthermore, reflecting on the criticism of the modernity/coloniality research 
programme, I consider it not so much a dogmatic set of prescriptions than an approach to other disciplines, theories or practices that integrates a decolonial analysis. ${ }^{82}$

\section{Buen Vivir and Rights of Nature} right to a god life, inspired by sumak kawsay/sumaq qumana (Buen Vivir or Living Well). These concepts reflect Amazonian-Andean indigenous ways of knowing and being, which embed humans in a spiritual and material relationship with their surroundings. ${ }^{86}$ Their constitutional mandate is subordinating the economy to societal and ecological well-being. As such, nature's intrinsic value is recognised, breaking with "the prevailing Western anthropocentric position in which humans are the only subjects of value," and rejecting nature's instrumentalisation by humankind. ${ }^{87} \mathrm{~A}$ fulfilled life according to the Aymara concept of sumaq qamaña is generated by two complementary lines of economic production within a given territory (ayllu): a material and a spiritual one. ${ }^{88}$ Processes that create sentiments and affectivity towards the earth, for example rituals or the humanisation of agricultural products such as potatoes, serve to limit overexploitation and an understanding of the earth as inert material, while also creating the spiritual dimension to a fulfilled person (chuymani, a person of/with heart). ${ }^{89}$ These historically, socially and environmentally specific concepts call upon us to transition from environmental justice based on human rights of the third generation to ecological, multi-species justice based on the rights of nature. ${ }^{90}$ As such, they ought to be of inherent interest to the degrowth debate.

Recent academic attention paid to Buen Vivir can be seen as part of the contemporary "ontological turn" that challenges the nature/culture divide in social sciences and humanities. ${ }^{91}$ The contestation of what is perceived to be "real" and the accompanying acknowledgment of possible ontological pluralisms may on the one hand gestate decolonial modes of thinking that would certainly be welcomed by those concerned with decolonisation and the discontinuation of epistemic violence. ${ }^{92}$ On the other hand, if degrowth was to explore these avenues, the "turn toward Indigenous ontologies [may] retrench, rather than redress, colonial forms of knowledge production." ${ }^{93}$ This is argued to occur when (often non-indigenous) researchers examine the intersections of indigeneity and ontology and neutralise the discourse's potential to decolonise knowledge by upholding academic, i.e. non-indigenous, standards of knowledge production and dissemination. Financially, prestigiously and politically, these standards serve a small, wealthy and non-indigenous proportion of the global 
population. ${ }^{94}$ Research that engages with indigenous knowledge therefore mustn't appropriate it, as is done when indigenous knowledge is represented as academic knowledge. ${ }^{95}$ Latour's challenges to the nature/culture divide have been criticised in this regard, in particular his contention that the climate represents an organising form in the Anthropocene. ${ }^{96}$ Far from being original, Todd criticises Latour for failing to reference the various Inuit, Anishinaabe, or Nehiyawak cosmologies to which his claim is analogous:

[We are] celebrating and worshipping a European thinker for "discovering," or newly articulating by drawing on a European intellectual heritage, what many an Indigenous thinker around the world could have told you for millennia: the climate is a common organizing force! ${ }^{97}$

To avoid ignoring indigenous traditions, or otherwise applying indigenous thought to Euro-Atlantic debates such as degrowth without accounting for the embodied, legal or spiritual aspects of it, any such contribution that aims to decolonise the debate (e.g. through "provincialising nature") must account for indigenous location and placethought on the one hand, and consider the on-going coloniality of the academy on the other hand..$^{98} \mathrm{~A}$ better understanding of what Buen Vivir means for indigenous communities may serve to help understand how in this case Kichwa cosmologies and social practices can contribute toward a decolonial framework for the politics of degrowth. ${ }^{99}$

In addition to specific indigenous place-thought, degrowthers could also turn to the discipline of ecology, however firmly rooted it may be in the study of non-human nature in the Western/Cartesian tradition. Research into the ecology of trees seems to affirm beliefs that acknowledge deep relationships between all living beings, delivering strong arguments in favour of rights of nature and ecological justice. Another lens through which to view this research can be to "anthropomorphise" or grant the possibility of agency to non-human beings. Using mycorrhizal networks, trees have been shown to communicate and cooperatively share nutrients with neighbours of different species, even dying ones. ${ }^{100}$ Moreover, they seem to engage in what can be described as friendships that last until the death of one partner, soon followed by the other, while sexual partners are able to mutually agree on an appropriate time for reproduction as well as feed and care for their offspring. ${ }^{101}$ When damaged by drought or pests, trees can send warning signals to other species. ${ }^{102}$ During severe drought, trees emit ultrasonic pulses that through their association with the tree's suffering have been described as "cries of thirst." ${ }^{103}$ Trees may also release rival-harming chemicals to boost their own species' growth. ${ }^{104}$

Their partnerships with fungi, as well as their mutual aid, competition and communication led Wohlleben to describe trees as "very social beings" - not far off from the web of relations between all living beings in an Andean ayllu, for example. ${ }^{105}$ Trees in particular seem suited to an analogy that culminates in the recognition of the rights of nature. This anthropomorphic representation of biological processes serves to highlight how the plant kingdom, much like the animal one, is capable of suffering, and merits rights and protection from harm. As seen in the case of BMW-Codelco, any extraction of materials like copper, perceived as "non-living" in the Cartesian tradition, invariably involves the suffering of "the living" world. "traditional" or "indigenous" (and thereby inferior). ${ }^{106}$ Scientific research could 
therefore align with demands for a "Living forest," a sacred territory that would form a non-proprietary, new legal category of protected area. This proposal has been made by the Kichwa people of Sarayaku, Ecuador, and "recognizes that the forest is made up entirely of living selves [including spiritual beings] and the communicative relations they have with each other." ${ }^{107}$ Recognising and reflecting on non-Western ontologies and epistemologies could therefore challenge the degrowth field's inherent Cartesian nature/culture dichotomy, which I have argued exacerbates the current ecological crisis. Additionally, such reflection may result in the recognition of the (indigenous) "Other" not as a "traditional" society that is the object of climate change mitigation and adaptation, but as equal agents.

\section{Conclusion}

This article has identified the Cartesian dualism of nature/culture as the cultural foundation of the economic growth paradigm. Over the course of five centuries, the view of nature as external to humans has facilitated the near total appropriation of the natural world as resources, i.e. inputs to the market economy. Violent colonial conquest and neo-colonial exploitation have underpinned this process in the past and continue to do so in the present. The degrowth debate presents a critical, well-founded challenge to the doctrine of unlimited economic growth and the social problems it produces. This article drew on the modernity/coloniality discourse, as well as indigenous scholarship and decolonial practice to suggest that the degrowth debate move beyond anthropocentric, Cartesian views of nature. In locating the degrowth debate within the decolonial struggles against the $\mathrm{CMoP}$, its Eurocentric focus is challenged without dislocating the discourse from its geographical and socio-economic places of relevance.

To overcome the Cartesian dualism of degrowth, I suggest replacing the language of "materials" with that of the "living world." speaking of the "living world" - a nonanthropocentric term - may challenge the subordination of nature to the economy (the "coloniality of nature"). Indigenous epistemologies and ontologies from the Andes, the Amazon and Chiapas substantiate the argument that our way of thinking influences how we think of and relate to the living world. Attributing agency to the living world may therefore result in a paradigm shift that considers humans as part of nature, rather than its masters. In conclusion, I suggest that the degrowth debate move toward ecological, multi-species justice based on the rights of nature. Such a focus would not only delink the degrowth debate from the CMoP, but also address the pressing issues of ecological debt and environmental justice.

\section{NOTES}

1. Corinna Dengler and Lisa Marie Seebacher, "What About the Global South? Towards a Feminist Decolonial Degrowth Approach,” Ecological Economics, vol. 157, March 2019, pp. 246-52. 
2. Research \& Degrowth, "Degrowth Declaration of the Paris 2008 Conference," Journal of Cleaner Production, vol. 18, $\mathrm{n}^{\circ}$ 6, April 2010, pp. 523-24.

3. Joan Martinez-Alier, "Socially Sustainable Economic De-Growth," Development and Change, vol. 40, n6, 2009, pp. 1099-1119.

4. François Schneider, Giorgos Kallis, and Joan Martinez-Alier, "Crisis or Opportunity? Economic Degrowth for Social Equity and Ecological Sustainability. Introduction to This Special Issue," Journal of Cleaner Production, vol. 18, n%, April 2010, pp. 511-18.

5. Giacomo D'Alisa, Federico Demaria, and Giorgos Kallis (eds), Degrowth: A Vocabulary for a New Era, Abingdon, Routledge, 2014, p. 3.

6. Inês Cosme, Rui Santos, and Daniel W. O'Neill, “Assessing the Degrowth Discourse: A Review and Analysis of Academic Degrowth Policy Proposals," Journal of Cleaner Production, vol. 149, April 2017, pp. 321-34.

7. Federico Demaria et al., "What Is Degrowth? From an Activist Slogan to a Social Movement," Environmental Values, vol. 22, n², April 2013, pp. 191-215.

8. Serge Latouche, Farewell to Growth, Cambridge; Malden, MA, Polity, 2009, p. 12; D'Alisa, Demaria, and Kallis (eds.), Degrowth, pt. I.

9. Latouche, Farewell to Growth; André Gorz, Ecology as Politics, London, Pluto Press, 1987.

10. Susan Paulson, “Political Ecology” in Degrowth, D'Alisa, Demaria, and Kallis (eds.), p. 46.

11. Ulrich Demmer and Agata Hummel, "Degrowth, Anthropology, and Activist Research: The Ontological Politics of Science," Journal of Political Ecology, vol. 24, 2017, pp. 610-622; Peter G. Brown, “Taking 'Evolution' Seriously: An Ontology for Degrowth," Conference Presentation, First North/South Conference on Degrowth, Mexico City, 6 September 2018, https://e4a-net.org/ 2018/10/09/taking-evolution-seriously-an-ontology-for-degrowth-by-peter-g-brown/.

12. Robert Costanza, “What Is Ecological Economics?” Ecological Economics, vol. 1, 1989, pp. 1-7.

13. Nicholas Georgescu-Roegen, "Energy and Economic Myths," Southern Economic Journal, vol. 41, n³, January 1975, pp.347-385.

14. Herman E. Daly, Ecological Economics and Sustainable Development: Selected Essays of Herman Daly, Northampton, MA, Edward Elgar, 2007, chaps 1, 23.

15. Blake Alcott, “Jevons' Paradox," Ecological Economics, vol. 54, n¹, July 2005, pp. 9-21.

16. Blake Alcott, "Impact Caps: Why Population, Affluence and Technology Strategies Should Be Abandoned," Journal of Cleaner Production, vol. 18, n6, April 2010, pp. 552-60.

17. Reinhard Madlener and Blake Alcott, "Herausforderungen für eine technisch-ökonomische Entkoppelung von Naturverbrauch und Wirtschaftswachstum unter besonderer Berücksichtigung der Systematisierung von Rebound-Effekten und Problemverschiebungen," Kommission “Wachstum, Wohlstand, Lebensqualität," Berlin, Deutscher Bundestag, 12 December 2011, pp. 44-48, 50-51.

18. ICA, "The Electric Vehicle Market and Copper Demand," Washington, DC, International Copper Association, June 2017, https://copperalliance.org/wp-content/uploads/2017/06/2017.06-EMobility-Factsheet-1.pdf.

19. Carlos Zorrilla, "The Role BMW May Play in Creating a World-Class Environmental Disaster in Ecuador," CATAP A, 27 March 2019, https://catapa.be/the-role-bmw-may-play-in-creating-aworld-class-environmental-disaster-in-ecuador/.

20. Carlos Zorrilla, DECOIN Anniversary, interview by Katharina Richter, 2 February 2020.

21. EJAtlas, "Environmental Justice Atlas," 2020, https://www.ejatlas.org/

22. Schneider, Kallis, and Martinez-Alier, "Crisis or Opportunity?"

23. Carl Sagan, "The Quest for Extraterrestrial Intelligence," Cosmic Search, vol. 1, n², 1979.

24. Edward L. Glaeser, "The Supply of Environmentalism: Psychological Interventions and Economics," Review of Environmental Economics and Policy, vol. 8, n², July 2014, pp. 208-29.

25. André Gorz, Critique of Economic Reason, London \& New York, Verso, 1989, p. 8. 
26. Kate Pickett and Richard Wilkinson, The Spirit Level: Why Equality Is Better for Everyone, London, Penguin, 2010.

27. OECD, "Unemployment Rate," 2017, https://data.oecd.org/unemp/unemployment-rate.htm; Hanna Wheatley, “The Rise of 'Bad Jobs'," New Economics Foundation, 15 August 2017, https:// neweconomics.org/2017/08/bad_jobs.

28. Cited from Serge Latouche, "De-Growth: An Electoral Stake?" The International Journal of Inclusive Democracy, vol. 3, n¹, January 2007; Giorgos Kallis, "Societal Metabolism, Working Hours and Degrowth: A Comment on Sorman and Giampietro," Journal of Cleaner Production, Degrowth: From Theory to Practice, vol. 38, Supplement C, January 2013, pp. 94-98.

29. Marco Deriu, “Autonomy” in D’Alisa, Demaria, and Kallis (eds.), Degrowth, pp. 55-58; Kallis, "Societal Metabolism, Working Hours and Degrowth."

30. Serge Latouche, "Degrowth: Misinterpretations and Controversies - Part 1 of 4," Essays on Frugal Abundance, Simplicity Institute, 2014, http://simplicityinstitute.org/wp-content/uploads/ 2011/04/FrugalAbundance1SimplicityInstitute.pdf.

31. Bengi Akbulut, "Carework as Commons: Towards a Feminist Degrowth Agenda," Degrowth.Info, 2 February 2017, https://www.degrowth.info/en/2017/02/carework-as-commons-towards-afeminist-degrowth-agenda/ ; Jukka Peltokoski et al., "Helsinki Time Bank: Currency as a Commons" in David Bollier and Silke Helfrich (eds.), Patterns of Commoning, Massachusetts: Leveller's Press, 2015.

32. D'Alisa, Demaria, and Kallis, Degrowth, p. xxvi.

33. Martin Weiss and Claudio Cattaneo, "Degrowth - Taking Stock and Reviewing an Emerging Academic Paradigm," Ecological Economics, vol. 137, July 2017, pp. 220-30.

34. Daniel W. O'Neill, “Measuring Progress in the Degrowth Transition to a Steady State Economy," Ecological Economics, vol. 84, December 2012, pp. 221-31; Ritu Verma, "Gross National Happiness: Meaning, Measure and Degrowth in a Living Development Alternative," Journal of Political Ecology, vol. 24, 2017, pp 425-666.

35. Rene Suša, "Modern Global Imaginaries, Modern Subjects, Enduring Hierarchical Relations and Other Possibilities," Postcolonial Directions in Education, vol. 5, n², 2016, pp. 193-216.

36. Walter D. Mignolo and Francisco Carballo, Una Concepción Descolonial Del Mundo: Conversaciones de Francisco Carballo Con Walter Mignolo, Ediciones del Signo and Center for Global Studies and the Humanities, Duke University, 2014, p. 23.

37. Aníbal Quijano, "Coloniality of Power, Eurocentrism, and Latin America," Nepantla: Views from South, vol. 1, n³, 2000, pp. 533-80.

38. Walter D. Mignolo, The Idea of Latin America, Malden, MA \& Oxford, Blackwell Publishing, 2005, p. 7.

39. Aníbal Quijano, "Coloniality and Modernity/Rationality," Cultural Studies, vol. 21, n²-3, 1 March 2007, pp. 168-78.

40. Maria Lugones, Isabel Jiménez-Lucena, and Madina Tlostanova, Género y Descolonialidad, Walter D. Mignolo (ed.), Ediciones del Signo and Globalization and Humanities Project, Duke University, Buenos Aires, 2008; Walter D. Mignolo and Arturo Escobar (eds.), Globalization and the Decolonial Option, London, Routledge, 2010; Quijano, "Coloniality of Power, Eurocentrism, and Latin America."

41. Walter D. Mignolo, "Delinking: The Rhetoric of Modernity, the Logic of Coloniality and the Grammar of de-Coloniality," Cultural Studies, vol. 21, n²-3, 2007, pp. 449-514.

42. Aníbal Quijano, “Colonialidad y Modernidad/Racionalidad," Perú Indígena, vol. 13, n²9, 1992, pp. 11-20.

43. Mignolo, "Delinking."

44. Ibid. 
45. Grosfoguel, "Transmodernity, Border Thinking, and Global Coloniality"; Walter D. Mignolo, "The Many Faces of Cosmo-Polis: Border Thinking and Critical Cosmopolitanism," Public Culture, vol. 12, n³, Fall 2000, pp. 721-48.

46. Walter D. Mignolo, “The Zapatistas's Theoretical Revolution: Its Historical, Ethical, and Political Consequences," Review (Fernand Braudel Center), vol. 25, n³, 2002, pp. 245-75.

47. EZLN, "Primera Declaración de la Selva Lacandona," Enlace Zapatista, 1 January 1994, http:// enlacezapatista.ezln.org.mx/1994/01/01/primera-declaracion-de-la-selva-lacandona/; Major Ana María, 1997 in Mignolo, "The Zapatistas's Theoretical Revolution."

48. Quijano, "Coloniality of Power, Eurocentrism, and Latin America."

49. Indigenous Peoples' Guide, “No to CO2lonialism!” False Solutions to Climate Change, 2009, http://www.uky.edu/ tmute2/nature-society/password-protect/nature-societypdfs/Indigenous-Peoples-Guide-Env.pdf

50. Herman E. Daly, John B. Jr. Cobb, and Clifford W. Cobb, For the Common Good: Redirecting the Economy Toward Community, the Environment, and a Sustainable Future, 2nd ed., Boston, Beacon Press, 1994, p. 112.

51. Arturo Escobar, "Degrowth, Postdevelopment, and Transitions: A Preliminary Conversation," Sustainability Science, vol. 10, n³, July 2015, pp. 451-62.

52. Maria Mies and Veronika Bennholdt-Thomsen, The Subsistence Perspective: Beyond the Globalised Economy, New York, Zed Books, 1999.

53. Except Brian Gilmore, “The World Is Yours: 'Degrowth,' Racial Inequality and Sustainability," Sustainability, vol. 5, n³, March 2013, pp. 1282-1303; Corinna Dengler and Birte Strunk, "The Monetized Economy Versus Care and the Environment: Degrowth Perspectives On Reconciling an Antagonism," Feminist Economics, vol. 24, n³, July 2018, pp. 160-83.

54. Boaventura de Sousa Santos, Conocer desde el Sur: Para una cultura política emancipatoria, Lima, Fondo Editorial de la Facultad de Ciencias Sociales, 2006, p. 125; Mignolo and Carballo, Una Concepción Descolonial Del Mundo, p. 31.

55. Edgardo Lander, "The Bolivarian Experience: A Struggle to Transcend Capitalism" in Miriam Lang, Claus-Dieter König, and Ada-Charlotte Regelmann (eds.), Alternatives in a World of Crisis, Brussels, Rosa Luxembourg Stiftung, 2018, pp. 48-50.

56. Fernando Coronil, "Naturaleza Del Poscolonialismo: Del Eurocentrismo al Globocentrismo" in Edgardo Lander (ed.), La Colonialidad Del Saber: Eurocentrismo y Ciencias Sociales. Perspectivas Latinoamericanas, Buenos Aires, CLACSO, 2000, p. 55; Eric Williams, Capitalism and Slavery, Richmond, VA, The University of North Carolina Press, 1944, chap. 5.

57. Lynn White, Machina Ex Deo: Essays in the Dynamism of Western Culture, Cambridge, Mass. \& London, MIT Press, 1968, 85-88.

58. Réne Dubos, "Franciscan Conservation versus Benedictine Stewardship" in Robert James Berry (ed.) Environmental Stewardship: Critical Perspectives - Past and Present, London \& New York, T\&T Clark, 2006, pp. 56-62; Ariel Hessayon, "Restoring the Garden of Eden in England's Green and Pleasant Land: The Diggers and the Fruits of the Earth," Journal for the Study of Radicalism, vol. 2, n², December 2008, pp. 1-25.

59. Gregory E. Hitzhusen, "Judeo-Christian Theology and the Environment: Moving beyond Scepticism to New Sources for Environmental Education in the United States," Environmental Education Research, vol. 13, n²1, February 2007, pp. 55-74.

60. Eleonora Montuschi, “Order of Man, Order of Nature: Francis Bacon's Idea of a 'Dominion' Over Nature”, Order: God's, Man's and Nature's, discussion Paper, Centre for Philosophy of Natural and Social Science, London School of Economics and Political Science, London, UK, 27-28 October 2010, p. 25.

61. René Descartes, A Discourse on Method, trans. Maclean Ian, Oxford, Oxford University Press, 2006 [1637]; Mignolo and Carballo, Una Concepción Descolonial Del Mundo, p. 30. 
62. Michel Baridon, "The Scientific Imagination and the Baroque Garden," Studies in the History of Gardens \& Designed Landscapes, vol. 18, n¹, March 1998, pp. 5-19; Montuschi, "Order of Man, Order of Nature."

63. Travel writer Gerald and historian Rice respectively, cited in Keith Pluymers, "Taming the Wilderness in Sixteenth- and Seventeenth-Century Ireland and Virginia," Environmental History, vol. 16, $\mathrm{n}^{\circ} 4$, October 2011, pp. 610-32.

64. Lowith, 1966, pp.155-156, cited in Hwa Yol Jung, "Francis Bacon's Philosophy of Nature: A Postmodern Critique," Trumpeter, vol. 10, n³, July 1993.

65. Mignolo and Carballo, Una Concepción Descolonial Del Mundo, p. 30.

66. Klaus Hubacek and Jeroen C. J. M. van den Bergh, "Changing Concepts of 'Land' in Economic Theory: From Single to Multi-Disciplinary Approaches," Ecological Economics, vol. 56, n¹, 2006, pp. $5-27$.

67. Whitehead, Martin Jones, and Rhys Jones, "Spatializing the Ecological Leviathan: Territorial Strategies and the Production of Regional Natures," Geografiska Annaler: Series B, Human Geography, vol. 88, $\mathrm{n}^{\circ} 1$, March 2006, pp. 49-65.

68. MacPherson, 1962, pp.142-159 in David Graeber, "Manners, Deference, and Private Property in Early Modern Europe," Comparative Studies in Society and History, vol. 39, n4, 1997, pp. 694-728.

69. Karl Polanyi, The Great Transformation: The Political and Economic Origins of Our Time, 2nd ed., Boston, MA, Beacon Press, 2001, p. 188.

70. Héctor Alimonda, "La colonialidad de la naturaleza: Una aproximación a la Ecología Política latinoamericana" in Héctor Alimonda (ed.), La naturaleza colonizada: ecología política y minería en América Latina, Buenos Aires, CLACSO, 2011, p. 51; Whitehead, Jones, and Jones, "Spatializing the Ecological Leviathan."

71. Edgardo Lander, "Eurocentrism, Modern Knowledges, and the 'Natural' Order of Global Capital," trans. Mariana Past, Nepantla: Views from South, 3, n², July 2002, pp. 245-68.

72. Elizabeth Barona et al., "The Role of Pasture and Soybean in Deforestation of the Brazilian Amazon," Environmental Research Letters, vol. 5, n², April 2010, pp. 024002.

73. Sarah A. Radcliffe, "The Difference Indigeneity Makes: Socio-Natures, Knowledges and Contested Policy in Ecuador" in Michela Coletta and Malayna Raftopoulos (eds.), Provincialising Nature: Multidisciplinary Approaches to the Politics of the Environment in Latin America, London, Institute of Latin American Studies, School of Advanced Study, 2016, pp. 161-62.

74. Kenneth E. Boulding, "The Economics of the Coming Spaceship Earth" in H. Jarrett (ed.), Environmental Quality Issues in a Growing Economy, Baltimore, MD, Johns Hopkins University Press, 1966, p.2.

75. Beatriz Rodríguez-Labajos et al., "Not So Natural an Alliance? Degrowth and Environmental Justice Movements in the Global South," Ecological Economics, vol. 157, March 2019, pp. 175-84.

76. Cf. the "politics of divergence" Marisol de la Cadena, Earth Beings: Ecologies of Practice across Andean Worlds, Durham, Duke University Press Books, 2015, pp. 147-48, 285-86; George Monbiot, "Here Are My Suggestions on How to Talk about the Living World," Twitter, 1 November 2018, https://twitter.com/GeorgeMonbiot/status/1057989766485102592.

77. O’Neill, "Measuring Progress"; Peter A. Victor, "Growth, Degrowth and Climate Change: A Scenario Analysis," Ecological Economics, vol. 84, December 2012, pp. 206-12; Nuno Videira et al., "Improving Understanding on Degrowth Pathways: An Exploratory Study Using Collaborative Causal Models," Futures, vol. 55, January 2014, pp. 58-77.

78. Rodríguez-Labajos et al., "Not So Natural an Alliance?"

79. Ibid.

80. Ariel Salleh (ed.), Eco-Sufficiency and Global Justice: Women Write Political Ecology, London, Pluto Press, 2009. 
81. Ariel Salleh, "Rio+20 and the Green Economy: Technocrats, Meta-Industrials, WSF and Occupy," Rio+20 Portal Building the Peoples Summit, 18 April 2012, http://rio20.net/en/documentos/ rio20-and-the-green-economy-technocrats-meta-industrials-wsf-and-occupy/\#fn-3191-16.

82. Silvia Rivera Cusicanqui, "Ch'ixinakax Utxiwa: A Reflection on the Practices and Discourses of Decolonization," South Atlantic Quarterly, vol. 111, n¹, January 2012, pp. 95-109; Arturo Arias, "From Indigenous Literatures to Native American and Indigenous Theorists: The Makings of a Grassroots Decoloniality," Latin American Research Review, vol. 53, n³, September 2018, pp. 61326.

83. Michela Coletta and Malayna Raftopoulos (eds.), Provincialising Nature: Multidisciplinary Approaches to the Politics of the Environment in Latin America, London, Institute of Latin American Studies, School of Advanced Study, 2016.

84. Carlos Taibo, ¿Por qué el decrecimiento?: Un ensayo en la antesala del colapso, Barcelona, Los libros del lince, 2014, p. 25.

85. Rosemary-Claire Collard, Jessica Dempsey, and Juanita Sundberg, "A Manifesto for Abundant Futures," Annals of the Association of American Geographers, vol. 105, n², March 2015, pp. 322-30.

86. Carlos Viteri Gualinga, "Visión indígena del desarrollo en la Amazonía," Polis [online], n³, December 2002, http://journals.openedition.org/polis/7678.

87. Eduardo Gudynas, “Buen Vivir”, in D’Alisa, Demaria, and Kallis (eds.), Degrowth, p. 202.

88. Martha Gonzales Cochi, "Ayni y reciprocidad en la lógica del jaqi/runa” in Koen de Munter et al. (eds.), Ecología y reciprocidad: (con)vivir bien, desde contextos andinos, La Paz, Plural Editores, 2017, p. 75 .

89. Ibid., pp. 74, 76, 78-79.

90. Ibid., p. 203; Donna Haraway, "Anthropocene, Capitalocene, Plantationocene, Chthulucene: Making Kin,” Environmental Humanities, vol. 6, n¹, January 2015, pp. 159-65.

91. Pablo Alonso González and Alfredo Macías Vázquez, “An Ontological Turn in the Debate on Buen Vivir - Sumak Kawsay in Ecuador: Ideology, Knowledge, and the Common," Latin American and Caribbean Ethnic Studies, vol. 10, n³, September 2015, pp. 315-34.

92. Emilie Cameron, Sarah de Leeuw, and Caroline Desbiens, "Indigeneity and Ontology," Cultural Geographies, vol. 21, n²1, 2014, pp. 19-26.

93. Ibid.

94. Sarah Hunt, "Ontologies of Indigeneity: The Politics of Embodying a Concept," Cultural Geographies, vol. 21, n²1, January 2014, pp. 27-32.

95. Zoe Todd, “An Indigenous Feminist's Take On The Ontological Turn: 'Ontology' Is Just Another Word For Colonialism," Journal of Historical Sociology, vol. 29, n¹, 2016, pp. 4-22; Vanessa Watts, "Indigenous Place-Thought and Agency Amongst Humans and Non Humans (First Woman and Sky Woman Go On a European World Tour!)," Decolonization: Indigeneity, Education \& Society, vol. 2, n¹, 2013, pp. 20-34.

96. Bruno Latour, "Agency at the Time of the Anthropocene," New Literary History, vol. $45, \mathrm{n}^{\circ} 1$, 2014, pp. 1-18.

97. Todd, “An Indigenous Feminist's Take."

98. Juanita Sundberg, "Decolonizing Posthumanist Geographies," Cultural Geographies, vol. 21, n¹, January 2014, pp. 33-47; Todd, “An Indigenous Feminist's Take;" Watts, "Indigenous PlaceThought and Agency."

99. This article is based on the author's Ph.D. studies at Goldsmiths, which include a case study of sumak kawsay (Buen Vivir) in Ecuador.

100. Suzanne W. Simard et al., "Net Transfer of Carbon between Ectomycorrhizal Tree Species in the Field," Nature, vol. 388, n6642, August 1997, pp. 579-82.

101. Peter Wohlleben, The Hidden Life of Trees. What They Feel, How They Communicate: Discoveries from a Secret World, London, HarperCollinsPublishers, 2017, pp. 5; 20; 32-36. 
102. Yuan Yuan Song et al., "Defoliation of Interior Douglas-Fir Elicits Carbon Transfer and Stress Signalling to Ponderosa Pine Neighbors through Ectomycorrhizal Networks," Scientific Reports, vol. 5, February 2015, pp. 8495.

103. Wohlleben, The Hidden Life of Trees, p. 48; WSL, "Trees: Rendering Ecophysiological Processes Audible - Projects," Swiss Federal Institute for Forest, Snow and Landscape Research, 24 July 2018, https://www.wsl.ch/en/projects/trees.html

104. James J Ferguson, Bala Rathinasabapathi, and Carlene A Chase, "Allelopathy: How Plants Suppress Other Plants," University of Florida, 2003, https://edis.ifas.ufl.edu/pdffiles/HS/ HS18600.pdf.

105. Wohlleben, The Hidden Life of Trees, p. 49.

106. Mark Bonta et al., "Intentional Fire-Spreading by "Firehawk" Raptors in Northern Australia," Journal of Ethnobiology, vol. 37, n4, December 2017, pp. 700-718.

107. Pueblo Originario Kichwa de Sarayaku, "Kawsak Sacha - Living Forest: A Proposal of the Kichwa People of Sarayaku for a New Protected Areas Category," 3rd International Rights of Nature Tribunal, Paris, 2015, https://www.culturalsurvival.org/sites/default/files/ Kawsak\%20Sacha\%20\%E2\%80\%93The\%20Living\%20Forest.UICN_.pdf ; Mirian Cisneros, Kawsay Sachay, interview by Katharina Richter, 07 March 2020.

\section{ABSTRACTS}

This article presents a sympathetic critique of degrowth scholarship, which reproduces anthropocentric, Cartesian views of nature. I suggest overcoming these by drawing on the modernity/coloniality discourse, as well as engaging with indigenous scholarship and decolonial practices such as Buen Vivir. I make the argument for extending agency and rights to non-human nature, beginning with a shift from the language of "materials" to that of "the living world." A focus on ecological, multi-species justice centred on the rights of nature would not only allow for a decolonisation of the degrowth debate, but also highlight issues around ecological debt and environmental justice.

\section{AUTHOR}

\section{KATHARINA RICHTER}

Katharina Richter is a PhD Candidate in the Department of Politics and International Relations, Goldsmiths, University of London. As an associate lecturer, she has taught political theory and international relations, with a special focus on colonialism and the making of the modern world. Her research interests include political economy, degrowth, Latin American politics and social theories, alternatives to development and decolonisation. Previously, she held a research assistant post at the Reiner Lemoine Institute in Berlin.

Contact: k.richter@gold.ac.uk

Department of Politics and International Relations, Goldsmiths, University of London, New Cross, London SE14 6NW, United Kingdom 